\title{
Article
}

\section{The Impact of the Construction of Large Reservoirs on the Cultural Landscape: A Case Study of the Shimen Reservoir, Taiwan}

\author{
Li-Yu Chen ${ }^{1}{ }^{(1)}$, Wen-Zhe Hsieh ${ }^{2}$ and Rung-Jiun Chou ${ }^{3, *(1)}$ \\ 1 Department of Interior Design, Chung Yuan Christian University, Taoyuan City 32023, Taiwan; \\ liyuchen@cycu.org.tw \\ 2 PhD Program in Design, Chung Yuan Christian University, Taoyuan City 32023, Taiwan; \\ achehsieh@cycu.org.tw \\ 3 Department of Landscape Architecture, Chung Yuan Christian University, Taoyuan City 32023, Taiwan \\ * Correspondence: rungjiun@cycu.edu.tw
}

Citation: Chen, L.-Y.; Hsieh, W.-Z. Chou, R.-J. The Impact of the Construction of Large Reservoirs on the Cultural Landscape: A Case Study of the Shimen Reservoir, Taiwan. Land 2021, 10, 1161. https:// doi.org/10.3390/land10111161

Academic Editors: Luís Carlos Loures and Thomas Panagopoulos

Received: 30 September 2021

Accepted: 28 October 2021

Published: 29 October 202

Publisher's Note: MDPI stays neutral with regard to jurisdictional claims in published maps and institutional affiliations.

Copyright: () 2021 by the authors. Licensee MDPI, Basel, Switzerland. This article is an open access article distributed under the terms and conditions of the Creative Commons Attribution (CC BY) license (https:// creativecommons.org/licenses/by/ $4.0 /)$.

\begin{abstract}
Reservoirs are large-scale water facilities with multiple functions, such as water supply, power generation, and tourism. This paper introduces the new community and cultural landscape formed by the indigenous people, engineers, workers who left their homes, and many migrating families at the Shimen Reservoir in Taoyuan, Taiwan, as an example. We analyzed how the community value of reservoir construction contributed to the development of the landscape through fieldwork, document review, and in-depth interviews. First, the new communities created to meet the needs of the immigrants influenced the surrounding environment and shaped a particular lifestyle. Secondly, new immigrants have formed a community consensus, and changes in the diet and natural landscape have promoted local tourism and affected the function of the reservoir. This study concludes that promoting local values through autonomous community action is a sustainable approach to community development. Tourism development with its symbiotic relationship with the reservoir can meet the needs of local socio-economic and cultural development. For sustainable development, a vulnerability study based on the Shimen Reservoir tourism is necessary.
\end{abstract}

Keywords: changing landscape; Shimen Reservoir; water construction; cultural landscape

\section{Introduction}

The 'landscape' usually describes all natural objects in the environment, including the relationship between various features in space, such as land, water, air, plants, and animals, including human beings [1]. Socio-Ecological Systems (SES) form a practical framework for analyzing the interactions between humans and nature, i.e., the development of landscapes from a socio-economic and ecological dimension. [2]. In Taiwan's Cultural Resources Law, "cultural landscape" is separated from the preservation of "natural cultural landscape" and defined as "the space and associated environment defined by myths, legends, monuments, historical events, community life, or ritual acts" [3]. Cultural landscapes are summarized in the Guidelines for the Implementation of the UNESCO World Heritage Convention for the Protection of the World's Cultural and Natural Heritage under three categories: 'landscapes designed and created intentionally by man', 'organically evolved landscapes', and 'associative cultural landscapes' [4]. Large-scale water facilities belong to the government-planned, reproduction space [5]. While settlements formed with public facilities belong to people's 'spatial practices.' The 'spatial practices' create a 'cultural landscape' that contains a cycle between 'spatial practices' and 'reproduced spaces'. Spatial practices are shaped by people's actions in space, which in turn shape space, which is extended by people's actions and constructs their cities according to their life needs [6]. This accords with the French philosopher Henri Lefebvre who, in his 1975 book La production de l'espace, referred to a triadic dialectic of spatial production, which included "spatial practices", "spatial reproduction", and "representational space" [7-9]. 
After 1895, when the Japanese government managed Taiwan, water resources were gradually nationalized, and government-run pond projects were initiated [10] to connect regional ponds and improve water supply. At this time, Taiwan did not have a modern multi-purpose reservoir, and in 1929, a project to build the Shimen Gorge Reservoir, called the Showa Water Conservancy Project, began [11]. However, due to the high cost of building the reservoir, the Shimon Gorge Reservoir project was not implemented until 1955 [12]. During the implementation process, U.S. investment assistance guided the engineers of the Shimen Reservoir Construction Committee in the design and inspection of the reservoir project, which marked the beginning of the formal introduction of U.S. engineering and inspection in Taiwan [13]. The project was led by the American Monk Group, which established various modern construction techniques, systems, and methods. The reservoir was finally completed in 1965, making it the largest multi-purpose reservoir in East Asia.

In Figure 1, dark blue shows the original Shimen Gorge River, light blue shows the current river area, and the red dots represent the location of aboriginal villages. Before and after the construction of the reservoir, the water area of the Shimen Canyon expanded, affecting the local aboriginal villages, including K'o-la-she, Chu-l'ou-chiao-she, and K'ueihui-she. Among them, the people of $\mathrm{K}^{\prime} \mathrm{o}-\mathrm{la}$-she were forced to move to a place very far away from the reservoir [14]. According to the official statistics, the relocated residents included 128 households of the Atayal indigenous people and 416 Han Chinese families, totaling 2870 people [15].

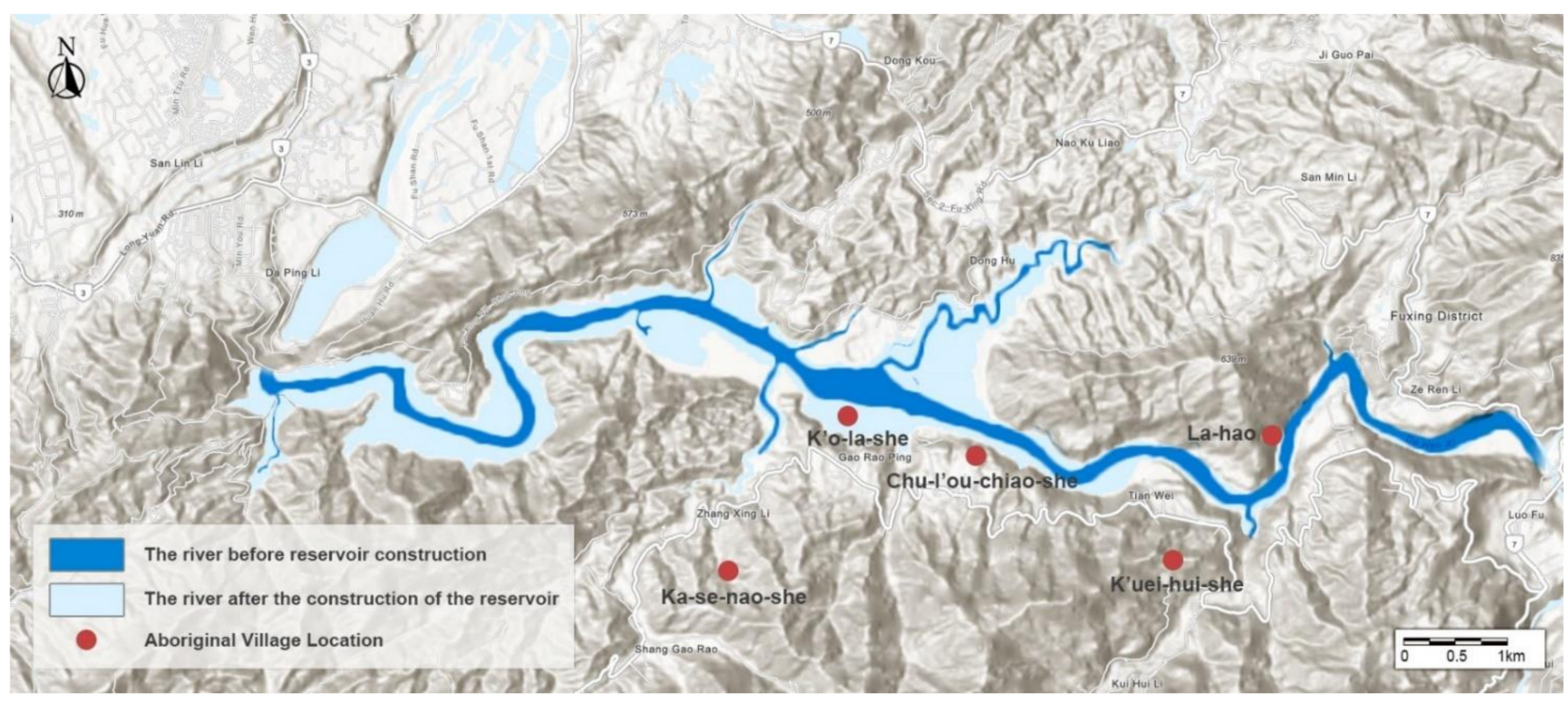

Figure 1. The river before and after the construction of the Shimen Reservoir. Source: 1960 Shimen Reservoir inundation area cadastral map. Esri, DeLorme, HERE, TomTom, Intermap, increment P Corp., GEBCO, USGS, FAO, NPS, NRCAN, GeoBase, IGN, Kadaster NL, Ordnance Survey, Esri Japan, METI, Esri China (Hong Kong), swisstopo, MapmyIndia, and the GIS User Community.

The Shimen Reservoir is an important water conservation facility in Taiwan as well as the first reservoir with multiple functions, such as water storage, power generation, flood control, tourism, and leisure. It set the standard for future water conservation in Taiwan and even became a symbol for Taiwan's reservoirs; however, the people who were forced to move because of the construction of the reservoir faced a life away from their hometowns while being replaced by the new people who moved in. In the 54 years since the new immigrants moved in, the cultural and natural landscapes of the reservoir's living area have been greatly altered by the construction of the reservoir, and the natural repercussions have affected the lives of the residents. Therefore, the following questions are raised in this study: 
1. Did the construction of the Shimen Reservoir have any real effect on the residents of the original community?

2. How can the old and large-scale government dormitories be renovated and adapted for reuse by the community?

3. In the face of climate change, how can the reservoir strike a balance between the tourism industry and the maintenance of the natural environment?

Therefore, this qualitative study focuses on the development and changes in the urban planning area of Shimen, including the dormitory area of Shimen Reservoir, the neighboring communities of Daping and Sankeng, after the construction of the reservoir, as well as the development and change of the live fish dining industry that flourished because of the Shimen Reservoir. The study also examines the economic development and food culture changes around the reservoir after many new immigrants entered the reservoir area. We also study the growth and changes of the community from the perspective of the cultural landscape and spatial production. The significance of the study is to provide a case study for cultural landscape and local development. Finally, we review the relevant literature and describe the data collection and analysis methods to explore how local development and cultural landscapes are balanced with natural landscapes and, finally, to draw conclusions.

\section{Literature Review}

Taiwan has steep terrain and fast rivers [16]. The 10-year average rainfall from 2003 to 2012 was about $2722 \mathrm{~mm}$ [17], which is 2.6 times the global average annual rainfall [18], yet Taiwan experiences water shortages every year [18]. To store and manage water resources effectively, the government currently has up to 94 reservoirs in actual operation throughout Taiwan [19].

The construction of the reservoir provided an artificial and functional facility that permanently changed the natural environment. It is also an "important element of personal and social well-being". Since the landscape arises from the daily life of human beings, it should be regarded not only as a heritage from the past but should be managed for the future [4]. In Taiwan, the water conservancy construction in Taoyuan has a history of nearly 100 years and a rich culture of historical stories. The most significant difference between it and other historical landscapes is that it is still a surviving spatial trace, a sustainable cultural landscape that contributes to sustainable business development [20].

In 1957, K.A. Wittfogel [21] proposed the concept of the Hydraulic Civilization, which was studied in Egypt, Mesopotamia, the Indus River Basin, and the Yellow River Basin, and argued that the government further dominated people's lives through the construction of hydraulic facilities, a so-called Hydraulic Society. Burton Pasternak [22] proposed the concept of the Sociology of Irrigation in 1972 and used the case of two villages in Taiwan to illustrate the social relationships formed by sharing a water system. From the perspective of landscapes, spaces, reservoirs, rivers, and lakes are all independent ecosystems, but reservoirs are artificial ecosystems built to meet human needs and may affect natural hydrology [23]. The boom in reservoir construction reached its peak in 1970, so most of the world's reservoirs are probably only about 50 years old [24]. Reservoirs may age more quickly than rivers and lakes that may have existed for millennia [25]. Thus, the construction of reservoirs fundamentally changes the geography and may radically change the entire river system and the ecology of the catchment [26].

Multifunctional reservoirs can still contribute to water supply, irrigation, flood control, energy generation, and even global climate change mitigation [27]. However, the construction of reservoirs is a pure water resource function and affects many land demands and interests and may bring new demands [27]. In addition to the demand for water supply brought about by multifunctional reservoirs, the demand also generates structural changes with a strong tourism orientation, thereby increasing additional demands from related stakeholders [28]. 
Water conservation in Taiwan can be divided into three phases: the Qing Dynasty, the period of Japanese rule, and the modern era [29]. During the Qing dynasty, most of the ponds were dug by the people themselves, and the government built few hydraulic facilities [30]. Hence, the development of water resources belonged to the early reclamation by the residents, which was a cooperative form of water development [31]. During Japanese rule, large-scale water conservation facilities and projects began to be developed. The government intervened to build an irrigation area covering more than half of the Taoyuan area in Taiwan, outlining Taoyuan's water conservation [29]. In modern times, with the technical support of the United States, the construction of the Shimen Reservoir began.

As the first multifunctional reservoir in Taiwan, it has been 57 years since its completion. The reservoir has brought water supply, power generation, and tourism value based on cultural services [32]. Under the boom of tourism development, the study of socialecological systems (SES) based on reservoir tourism has become a necessary project in the face of the changing natural environment and human-social changes [33]. This includes both natural and human systems and the scope covers the resource system, the economic infrastructure, and social, governmental, and personal development subsystems that are closely related to human beings [34]. Additionally, the study of SES is developed based on social, economic, environmental, and institutional factors [35].

When people's economic level improves, reservoir tourism integrates the development of nature and humanity. There is usually a contradiction between regional development and ecological protection [36] so that over-exploitation may lead to the depletion of resources in tourist areas [37]. In 2004, the Shimen Reservoir had the dilemma of not supplying water due to the increased turbidity of raw water caused by typhoon "Aere" [38].

Therefore, in the face of the normalization of disasters, social ecosystems have begun to emphasize the importance of "resilience", which is considered to involve improvements to further cope with changes and to achieve the possibility of environmental control and management [39]. The cultural landscape is not only a function or a unidirectional flow from a natural to a human ecosystem, but it is generated through the interaction between humans and the environment [40]. Therefore, the study of the vulnerability of socioecological systems based on reservoirs is bound to become an important project for the region's sustainable development $[41,42]$.

New demands change the landscape and, according to Henri Lefebvre (1901-1991) [9], space is social and changes with history and lifestyles. Thus, space dominates and embodies the products of human consciousness materialized through productive activities and matrices [43]. In other words, social space is formed by the people who used to live in a habitable environment. The reservoir was a necessary public project for the entry of human beings into an industrial society. For Lefebvre, it was the realization of "spatial reproduction". In contrast, the people who gathered due to the construction of the reservoir and developed a unique social structure were part of the local people's process of "spatial practice". The relationship between them was created, and a cycle was formed.

\section{Methods}

The sources of the data collected for this study included (1) fieldwork to understand the current situation and the development direction of the Shimen Urban Planning Zone, (2) a review of documents from before and after the construction of Shimen Reservoir, and (3) in-depth interviews in which people live within the reservoir community could share stories and details about the reservoir before and after development, as described in the following sections.

\subsection{Fieldwork}

The site of this study is around the Shimen Reservoir in Taoyuan, Taiwan, which is a landmark as the first sizeable multi-purpose reservoir in Taiwan. In addition, the construction process forced out the aboriginal people and employed many laborers, thus creating a new community. The area around Shimen Reservoir has, unlike the areas surrounding 
other reservoirs in Taiwan, developed a unique recreational and live fish dining industry. In addition to the reservoir, the Bei Tang landscape culture in Taoyuan is a potential World Heritage site. From the reservoir in the upper reaches to the Bei Tang in the lower reaches, all areas of Taoyuan are linked together by canals, which is a landscape phenomenon unique to the Taoyuan area.

The field survey period of this study was from 2019 to 2021. The scope of the survey was mainly the planned area of Shimen City, centered on Shiyifen Jifu Palace and including the old live fish street, Jia'an W. Road, and the new live fish street, covering the Wenhua Road from Shimen Elementary School to the Northern Region Water Resources Office. The detailed survey site areas are shown in Figure 2. The dormitory area is divided into the Shiyuan First Village dormitory group surrounded by Meiguo Road and Shiyifen, extending from Jia'an Road to Jia'an W. Road as the primary survey route. Outside the dormitory area, the Daping and Sankeng Communities, the earliest historical developments of Longtan Township, were once very lively because of the construction of the reservoir. Even after the construction of the reservoir, they were included in the scope of the Shimen Urban Planning Zone (Figure 2), but this changed due to various factors. Today, these two communities have developed different appearances. Therefore, this study is divided into five survey areas according to the scope of the current Shimen Urban Plan. These five areas are:

1. Sankeng Community.

2. Shiyifen Northern Region Water Resources Office and Shimen Reservoir dormitory group.

3. Daping Community.

4. The Erping area (the dormitory has been demolished).

5. Nanyuan Park (former Shimen Reservoir Construction Quarry and later Asian Paradise).

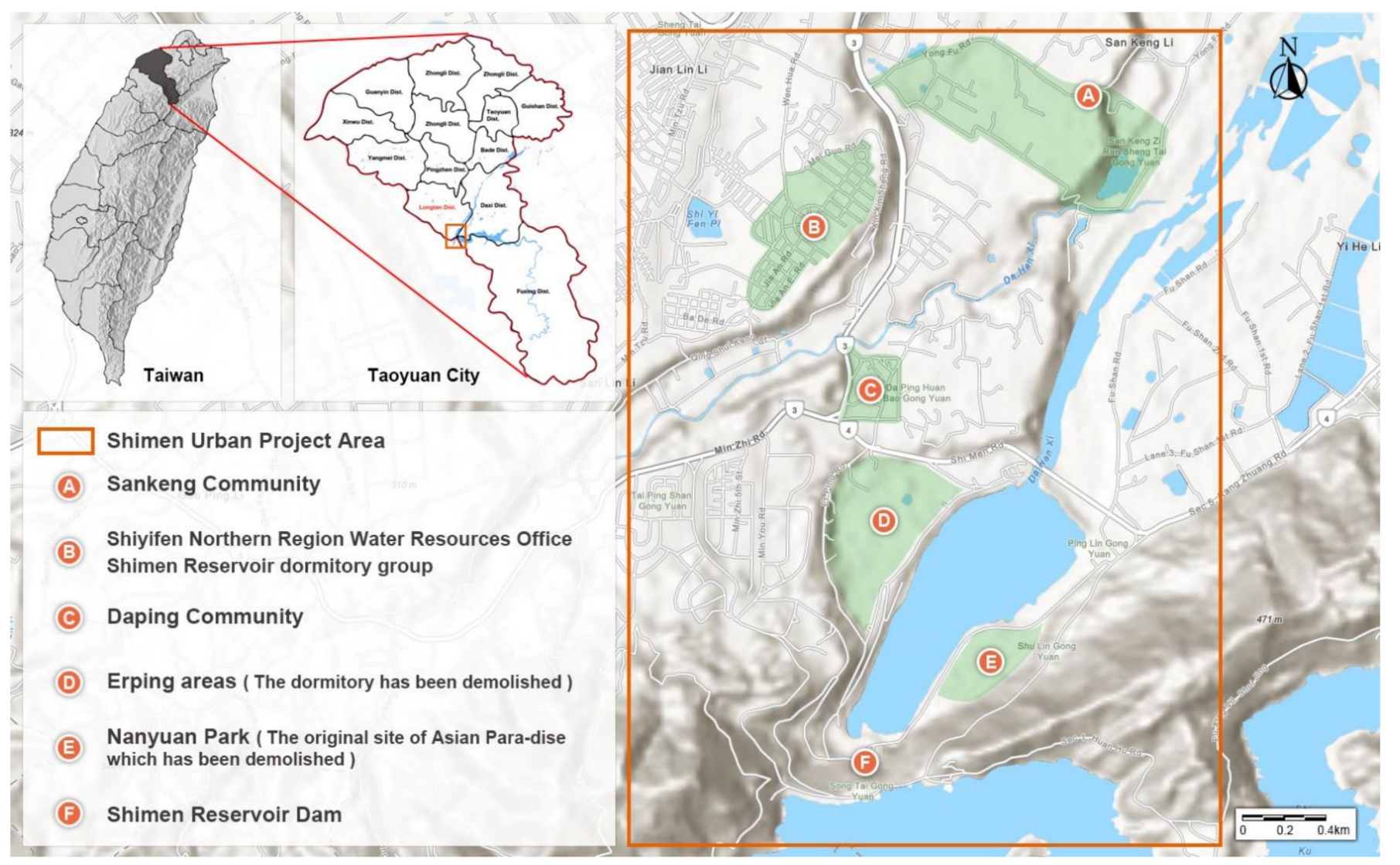

Figure 2. 2020 Taiwan Taoyuan Shimen Reservoir River Area and Urban Plan Location Map. Sources: Esri, DeLorme, HERE, TomTom, Intermap, increment P Corp., GEBCO, USGS, FAO, NPS, NRCAN, GeoBase, IGN, Kadaster NL, Ordnance Survey, Esri Japan, METI, Esri China (Hong Kong), swisstopo, MapmyIndia, and the GIS User Community. 


\subsection{Document Review}

It has been 57 years since the construction of the Shimen Reservoir. During this period, in addition to the residents who moved in for the construction of the reservoir, more people moved in after the completion of the National Chung-Shan Institute of Science and Technology (NCSIST) and the nearby industrial development and the community continued to flourish. Over time, many of the earliest construction sites ceased to exist, such as the temporary dormitory at Erping which was demolished. The residents who moved here are older and experience many inconveniences. Therefore, this study focuses on analyzing the data on the construction of Shimen Reservoir and the changes in the social environment.

The total period of data analysis is from 1966 to 2021. The data allows us to explore the literature from the beginning of the reservoir construction and study and compare the maps of the early reservoir construction with the present-day maps in order to create overlapping maps. The scope of the analysis of the papers and monographs includes known papers discussing the migration associated with the reservoir, literature on the contents of the project, videos and news from television interviews, and other related materials.

\subsection{Interviews}

In addition to fieldwork, in-depth non-structured interviews were conducted with residents and experts familiar with local development characteristics to obtain first-hand information about the area. To enhance the credibility and the results of the study, a purposive sample of respondents who have been involved in community-related issues for a long time or those who have been directly affected by the changes in the reservoir was selected. A few questions were asked first, and then the respondents told their stories about living in each community to ensure the authenticity of the interview data. Based on the interviews, the most accurate content was obtained through appropriate in-depth questioning. The sampling criteria for the respondents were as follows:

1. Residents living in the Shimen Project area.

2. Those who have been involved in activities and organizations in the local community for a long time.

3. Residents whose lives have been affected by changes in the reservoir (water outages).

The questions asked during the interview process were based on respondents living in different areas and included:

1. Whether the government's planning and renovation in response to the community development has exerted the necessary influence.

2. The nature of the changes in the community during the construction of the reservoir and the current situation.

3. Whether the community has been renovated and planned as in the Shimen Urban Planning Area.

4. How do we view the current tourism industry and the future development of the reservoir?

5. Whether the siltation of the reservoir has affected the life of Taoyuan when it is facing a major water outage.

6. From the perspective of cultural landscape development, how do we balance community development and economic benefits?

7. Whether the government has made positive contributions to the development of the cultural landscape.

A total of six in-depth interviews were conducted during the interview period from July 2019 to March 2021 (Table 1), with an acceptance rate of 100\%. These included:

1. IV1, a local teacher who used to live in the Dam Engineering Office dormitory and later moved to the Stone Authority dormitory.

2. IV2, an owner of a live fish restaurant, who had moved out of Stonegate Canyon as an indigenous person and came back to the reservoir to run a live fish restaurant. 
3. IV3, an engineer who lives in Taixi and is unable to live normally because of the water cut-off in the reservoir.

4. IV4, a housewife living in Bade, Taoyuan, whose life was affected by the reservoir's water failure.

5. IV5, a local chief whose ancestors have been cultivating the local land temple and who is familiar with the local development and construction process of the reservoir.

6. IV6, a local resident who has lived in the community around the reservoir since childhood and is involved in local affairs.

Respondents who were residents of the area around the reservoir and those people who were affected by the water cuts were interviewed on an unpaid basis. The respondents' basic information was divided into different areas, as shown in Table 1.

Table 1. Basic data of the interviewees.

\begin{tabular}{cccccc}
\hline Basic Data of the Interviewees & Age & Gender & \multicolumn{2}{c}{ Identity } & Residence \\
\hline A & 58 & Male & Teacher & Longtan \\
\hline B & 60 & Male & Resident of Daping Neighborhood & Longtan \\
\hline C & 55 & Male & Resident of Daping Neighborhood & Longtan & Dasi \\
\hline D & 42 & Male & Engineer & Bade \\
\hline E & 70 & Female & Retired housewife & Longtan \\
\hline F & 50 & Male & Live fish shop owner &
\end{tabular}

A thematic analysis method was used to study the data from the field survey, interviews, and documentary analysis. Since thematic analysis is a flexible method of qualitative analysis [44], this study used it to analyze the qualitative data [45], including interview data and the data observed in the documentary text and fieldwork, and presented the results thematically to help explain the meaning of the text [46]. In the process, we observed data related to community identity, cultural landscape, and the reservoir's exceptional food and tourism. The four main points of the study are:

1. Reservoir Newcomers and Dormitory Clusters.

2. The Current State of the Old Stone Gate Neighborhood-Daping Community.

3. The Current State of the Old Stone Gate Neighborhood-Sankeng Community.

4. The current situation of the sightseeing and amusement areas.

5. The live fish tourism industry.

The relationship between the detailed research data, research methods, and research objectives is shown in Figure 3.

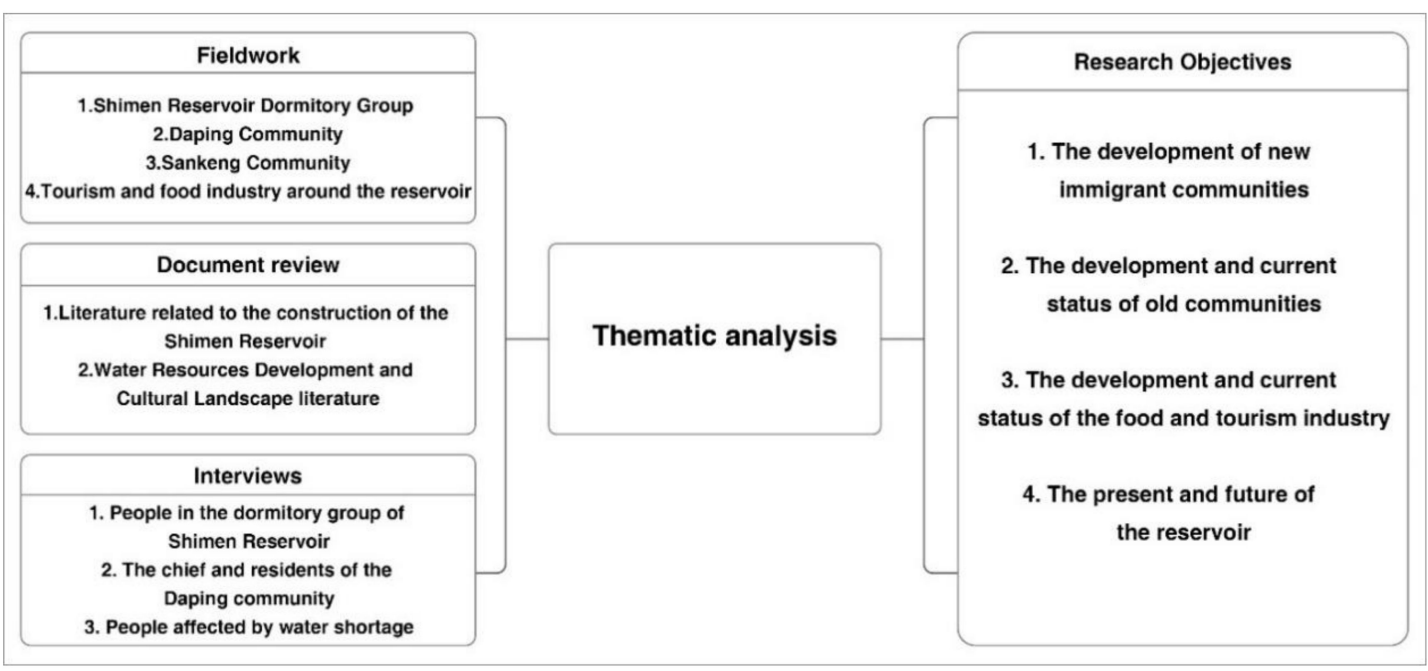

Figure 3. Schematic diagram of the research framework. 


\section{Results}

In this study, fieldwork was conducted based on the study area. Since the Erping dormitory area was demolished long ago, the scope of the study consisted of five regions, namely (1) Shiyifen Northern Region Water Resources Office dormitory group, (2) Daping Community, (3) Sankeng Community, (4) Restaurant group around Shimen Mountain, and (5) Nanyuan Park.

\subsection{Reservoir Newcomers and Dormitory Clusters}

As shown in Figure 4, at the beginning of the construction of Shimen Reservoir, to smooth the construction and provide a large number of stationed workers with a place to live, the Shimen General Office and Shimen Reservoir Construction Committee were established in the Longtan Jia'an area, Taoyuan.

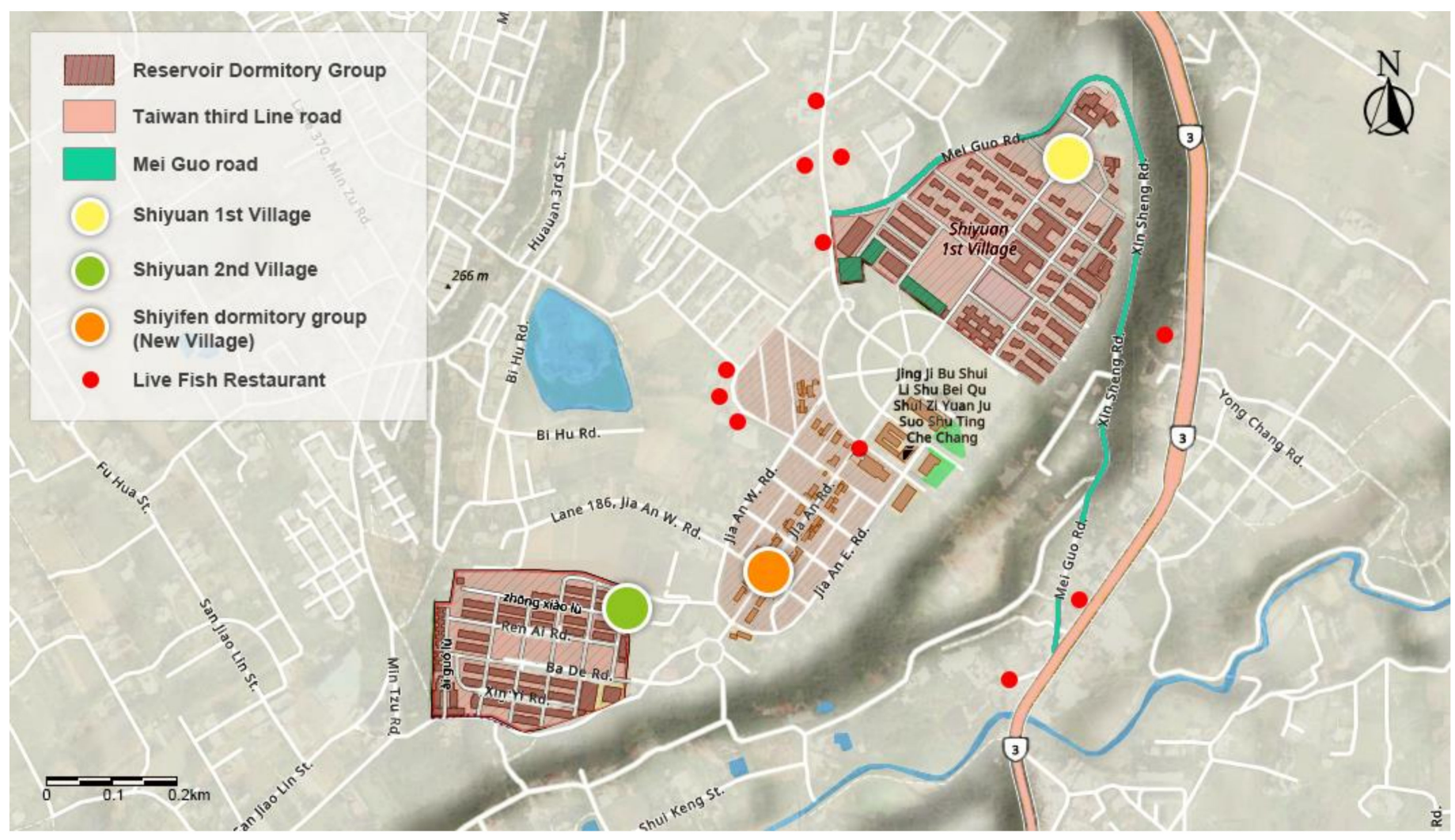

Figure 4. Location map of the reservoir dormitory groups. Sources: Esri, DeLorme, HERE, TomTom, Intermap, increment $\mathrm{P}$ Corp., GEBCO, USGS, FAO, NPS, NRCAN, GeoBase, IGN, Kadaster NL, Ordnance Survey, Esri Japan, METI, Esri China (Hong Kong), swisstopo, MapmyIndia, and the GIS User Community.

However, Shiyifen Village could not accommodate all the staff, so the dam engineering department and dormitory were set up in the former Erping areas. At that time, the number of reservoir workers stationed in Shiyifen was as high as 7000. If family members were included, the population moving into the area might exceed 10,000. The main types of residents moving into the area were:

1. American consultants.

2. Employees of the Shimen Reservoir Construction Committee (Northern Region Water Resources Office).

3. Workers building the reservoir.

4. Residents who have started commercial activities depending on the reservoir.

To carry out the project, the number of American engineers was about 65, and if we added the dependents, the number was about 110 [47]. To meet the lifestyle of American employees, Shiyuan First Village's environmental planning was the same as the design of 
an American villa community, with complete internal public facilities and guard kiosks. Moreover, to help American employees quickly reach the reservoir project site, the direct "Xinsheng Road" was opened, which was later dubbed "Meiguo Road" by the surrounding residents. In March 2018, "Meiguo Road" became the official name for household administration [48]. After constructing the reservoir, American engineers left, and Shiyuan First Village remained a military control area and became the dormitory of the NCSIST and inaccessible to ordinary people. The second area is the Northern Region Water Resources Office dormitories on Jia' an Road located on the other side of Shiyuan First Village, including Jia'an Market, etc. To meet the living needs of Taiwanese technical employees, although the facilities and environment were not as comfortable and luxurious as Shiyuan First Village, it was still a single-family dormitory group. Now, it is part of the Shiyifen Cultural and Creative Park Resident Workstation. The three elements of the environment in Shiyuan 1 and Shiyuan 2 villages are blocks (buildings and grass), axes, and circles [49]. This dormitory group, along with the Taichung Guangfu New Village and Zhongxing New Village dormitory groups, is a model for public institution dormitories.

Shiyuan First Village was mainly created to serve the dormitory area designed and planned by American engineers. The park had a single house type and a complete plan with good public facilities, such as stadiums and hospitals [47], and new roads linked to the reservoir, among which Xinsheng Road. These villages were called "American Villages" by the villagers, with a broad area of nearly $109,878.46 \mathrm{~m}^{2}$. However, times have changed. With the completion of the reservoir and the neighboring Central Science Research Institute, the American engineers no longer live in the area. Xinsheng Road was renamed "Meiguo Road". The hospital remained open and was renamed the Shiwei United Clinic of NCSIST. Shiyuan Dormitory has become the dormitory for NCSIST engineers. Although it seemed to be gradually opening, the dormitory group of Shiyuan is still inaccessible at present, and the Shiyuan Clinic remains an exclusive clinic of the NCSIST and belongs to the military control area. However, manufacturers or employees related to the NCSIST can make an appointment to stay in the "Shiyuan Guest House" and experience the scenery in the control area.

The Northern Region Water Resources Office Dormitory Group, also known as the Shiyifen dormitory group and the "New Village" [47] by neighboring residents, is a large residential dormitory where local engineers live. It consists of single-family, singlecourtyard buildings and planned blocks (turf), axes (roads), and rings [49], which were arranged radially along Jia'an Road and Jia'an W. Road. Due to the migration of nearly 10,000 people, the initial dormitory space plan was insufficient, so a new collective residential dormitory, Shiyuan Second Village, was built covering a broad area extending to around 190,688 $\mathrm{m}^{2}$, almost double the size of the American Village.

The Shiyuan Dormitory Group is a combination of Japanese and American styles. Because of the changes in time and space, dormitories are getting old or becoming uninhabited [50]. The initially quiet street has caught people's attention because of the filming of 'Our Times' [51]. With the help of the movies, the Shiyifen Dormitory Park has become famous and has attracted the attention of government agencies that even planned to design the area as an "American Village" and introduce shops or Broadway theaters.

However, Interviewee A, who has lived in the area since he was a child, noted: "From the beginning, the term American village was used, and there was a deviation at the beginning because there was no cultural presentation of Americans living here in the local cultural and historical origin".

Government officials stopped planning the American village due to the strong disagreement of residents and literary and historical workers. They returned to the first proposal for a "Cultural and Creative Village". The development of the "Shiyifen Cultural and Creative Parks" hopes to link up the leisure spots around Shimen Reservoir to enhance the overall economic benefits of tourism [52].

The current official plan for the first phase is to rebuild the Jia'an market, which will not be extended to unoccupied residential houses until the second phase. However, 
starting from 2018, the Jia'an market was renovated. The former Jia'an market vendors were relocated to the old garden restaurant building beside the big lawn of the North Water Bureau.

Jia'an W. Road, located in front of the turf of the Northern Region Water Resources Office, is also the most controversial area, which belongs to the second phase of planning. Because the investment promotion in the first phase is not in good condition, this area still keeps its original appearance at present, and the elderly live here adjacent to the unoccupied houses. They have to keep the original residence quiet (Figure 5).
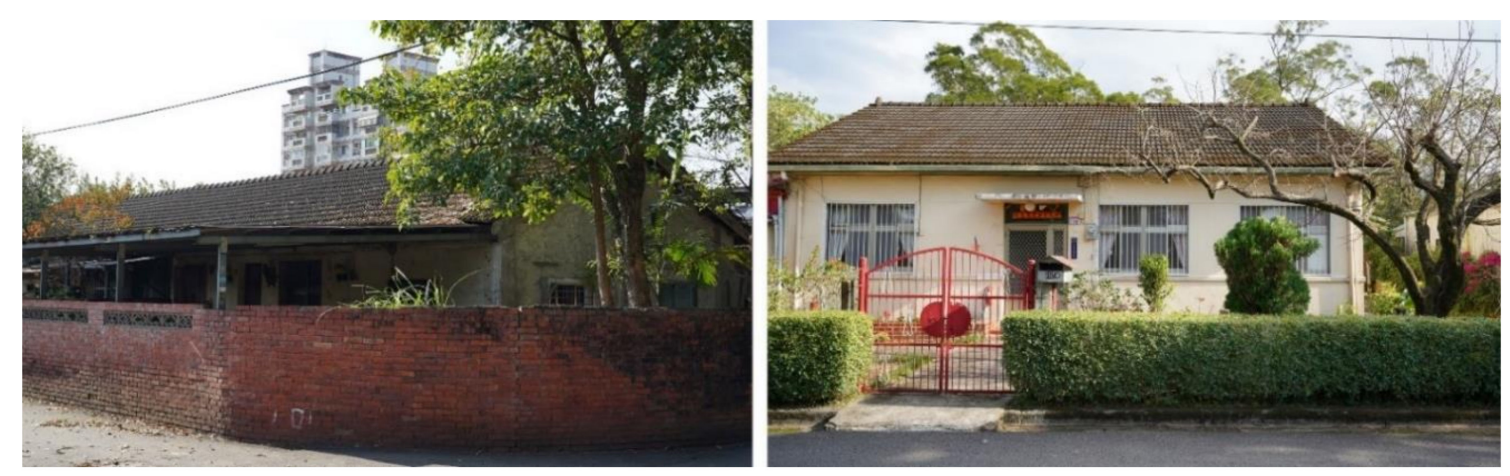

Figure 5. Old houses around Jia'an W. Road (source: Wen-Zhe Hsieh, all rights reserved and used with permission).

New immigrants who moved in since the construction of the Shimen Reservoir became the original inhabitants of the Shiyifen region and developed an emotional connection with the local environment and residence, the reservoir, or dormitory planning. They are all the government's spatial representation of existing land. Aboriginal communities who were forced to move because of the flooded reservoirs arrived at the renovated Jia' an Market due to the planning of the Shiyifen Cultural and Creative Park. Residents were forced to accept the blueprint planned by the government. Each time, the blueprint vision is to reproduce and practice the on-site environment. However, the government failed to understand the development process and history of the Shiyifen dormitory group in that year. The impact of this will be unused space in the new Jia'an market and permanent damage to the local environment and memory.

\subsection{The Current State of the Old Stone Gate Neighborhood-Daping Community}

The Daping Community is in the southeast of Longtan and connects with Sankeng to the north and Shimen Reservoir to the southeast (Figure 6). Because of its proximity to the mountains, in 1768, Hakka ancestors who originally lived in Guangdong, China, arrived here and built a settlement. However, since a commercial settlement had already formed at Sankeng with the main road of the river and port, there is also a saying that the rise of the Daping Settlement is an outpost (Yiyong outpost) set up to prevent Sankeng from being harassed by aboriginal communities [53].

Daping contains the most well-preserved bridge in Taiwan, the "Red Bridge", which is a crucial traffic artery between Sankeng and the Daping Community. At the initial stage of reservoir construction, the Red Bridge was an essential road between Sankeng and Daping. According to Yonghe Gongzhi, the Daping Community had a "big city" and "small city" in the early days, but the city walls no longer exist. The streets in this community are curved and narrow. The houses are closely connected, in a honeycomb structure, which verifies that the defensive buildings designed by Hakka ancestors to resist foreign enemies have now become the unique architectural style of the Daping Community (see Figure 7) and are known as the Daping Maze Lanes. 


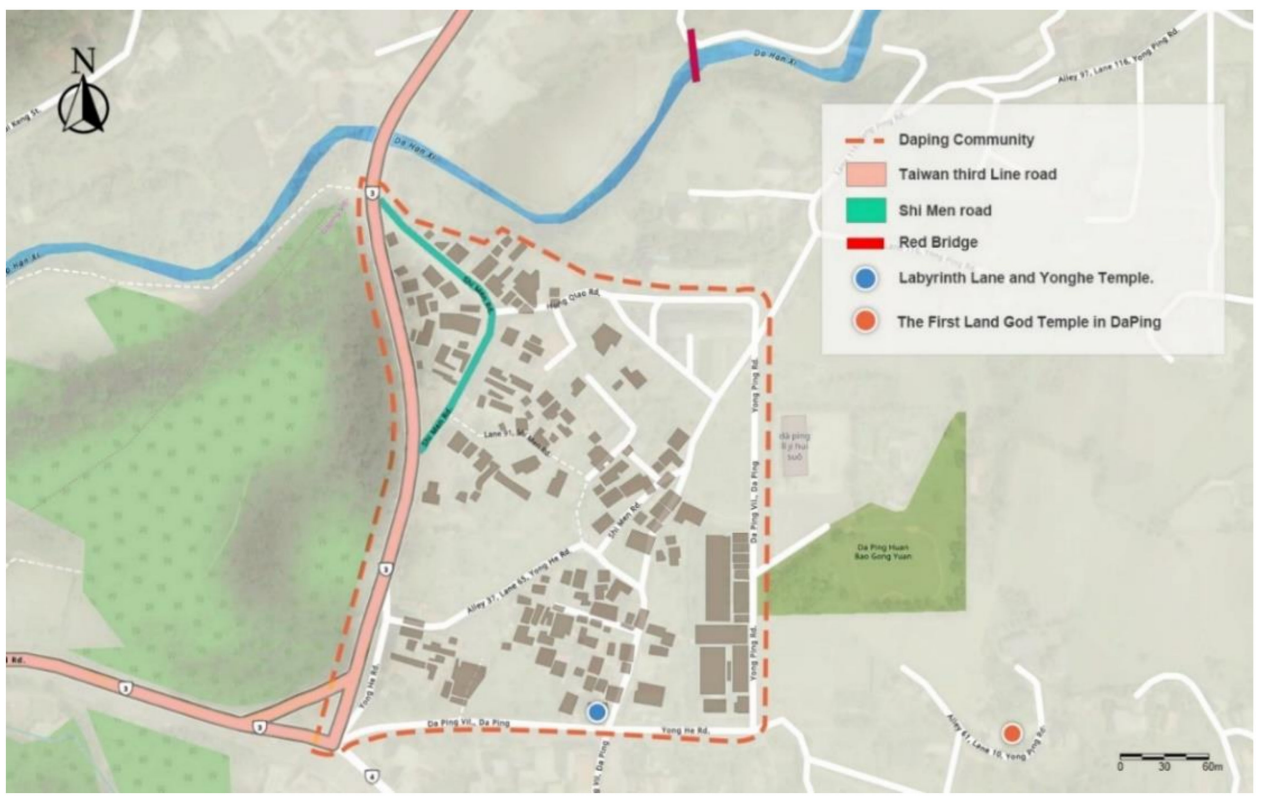

Figure 6. Location map of the Daping Community. Sources: Esri, DeLorme, HERE, TomTom, Intermap, increment $P$ Corp., GEBCO, USGS, FAO, NPS, NRCAN, GeoBase, IGN, Kadaster NL, Ordnance Survey, Esri Japan, METI, Esri China (Hong Kong), swisstopo, MapmyIndia, and the GIS User Community.
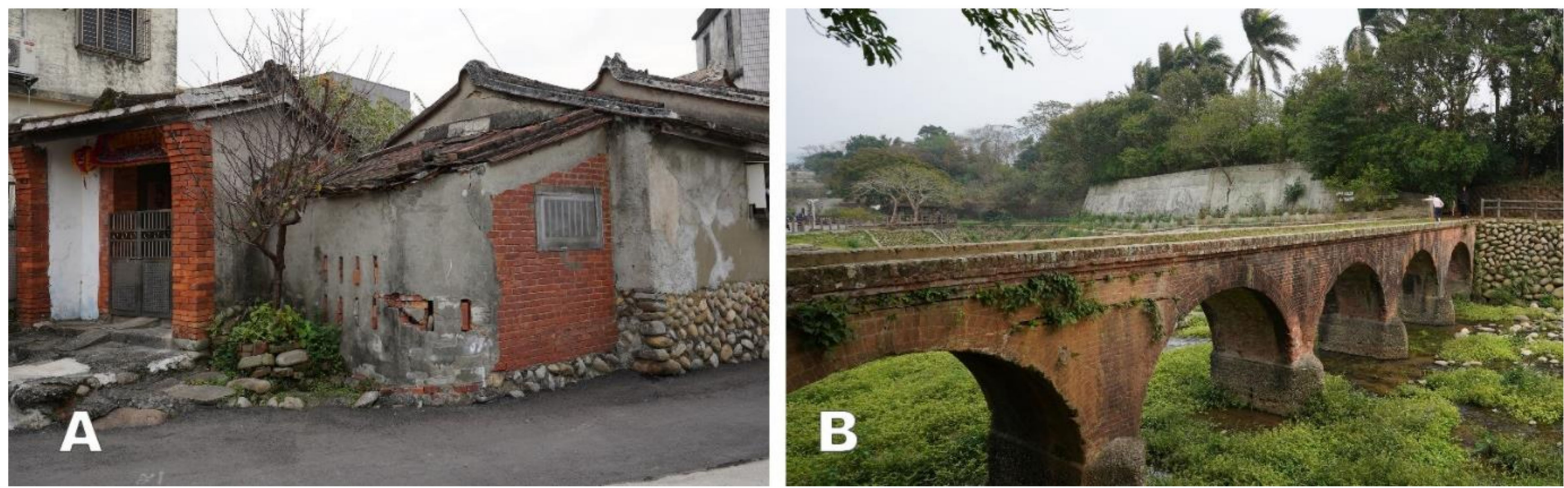

Figure 7. (A) Daping Community, a maze of alleys. (B) Daping Red Bridge (source: Wen-Zhe Hsieh, all rights reserved and used with permission).

The Daping Community was relatively prosperous when the reservoir was built. Interviewee B said, "When the reservoir was built, Daping neighborhood was quite lively. For the convenience of construction, a new road was opened next to Xidangjing to pass through the community, which is now Shimen Road. At that time, all the shops along the road operated for building the reservoir, and even sex industry workers gathered in the Daping neighborhood". Because the geographical location happened to be between the Shimen Reservoir and Sankeng Community, the Daping Community was home to many commercial activities when the reservoir was built. Interviewee $C$ also said, "My uncle bought vegetables here at that time. There was no car before. We all walked to sell vegetables near the reservoir". From the interviewee's description, we can understand that at the beginning of the construction of the reservoir, the community of Daping was a lively village, and most of the industries were linked to the reservoir. Shimon Road was built for the convenience of transportation.

The construction of the reservoir contributed to the economic and social development of Daping and a historic peak in its industrial and commercial prosperity. However, when the reservoir was completed, the Daping Community, initially set up in the Shimen Urban Planning Zone, was unable to carry out new construction and expansion due to the "no construction" and "prohibited construction" rules of Shimen Urban Planning. 
Interviewee B also expressed some feelings of injustice, "The high-rise buildings on the top of Erping Mountain in the reservoir are higher than each other, but the house building on our site is restricted". Understandably, residents are dissatisfied with the restrictions on construction. In addition, many workers living in the reservoir dormitory area also moved out, and the homeless population made the Daping Community no longer prosperous. However, the most direct factor affecting the development of the residential area may be the widened Taiwan Third Line road. The section was built to bypass the Daping Community. Vehicles that used to pass along Shimen Road now bypass the community along the next Taiwan Third Line road, which affects the development of the community. In response, the popularity of the Daping Red Bridge is increasing. Tourists frequently visit the Red Bridge, and there are even tour buses. However, due to road design factors, vehicles can only stay in the inner activity center area outside the residential area, and tourists would not be able to directly enter the residential area, resulting in its closed and quiet environment. The defensive buildings of the original Hakka ancestors are still completely preserved, but they are being allowed to decay. Compared with the neighboring Sankeng Community, the Daping Community has no main commercial activities and seems to form a forgotten area between Sankeng and the Shimen Reservoir.

\subsection{The Current State of the Old Stone Gate Neighborhood-Sankeng Community}

Sankeng Old Street is the earliest developed urban area in Longtan District and Taoyuan City (Figure 8). It is said that a community was established in 1744 because of its geographical location where three streams converge into Dahan Creek (Dakekan Creek), namely "Yamu Valley" located on the edge, "Huojiewei Pit" in the center, and "Zhebu Pit" in the south [54]. The pits and valleys formation led to the name "Sankeng". Additionally, goods shipped from northern Taiwan travel between Taoyuan and Taipei and Sankeng via Dahan Creek (Dakekan Creek) in the upper reaches of Tamsui River, which has created a port and distribution center for goods and agricultural products in Taoyuan [55]. As a result, a market to engage in commercial activities gradually arose and became an early symbol of development and prosperity. Therefore, it became known as "Longtan First Street".

The people forming the community first landed from the head of the second section of Tandu Ferry in Sankeng. It was the first stop of the "tea transportation waterway" in the past and became the transfer station for Taozhumiao Hakka Village tea; hence, it is also known as the "Hakka Tea Port". It is also the starting point of the current Hakka Committee's combination with the romantic Taiwan Third line in Taozhumiao's three counties and cities [56].

The "Yongfu temple" located in the city's center, was completed in 1744 (Figure 9). However, the "Kaizhuang Bogong Temple" and "Fengxiang Shenmu" behind the Yongfu temple may have been completed earlier. From the name "Kaizhuang", this was the area first developed by the ancestors when they arrived in Sankeng. Compared with the fortress building of Daping Community, the streets of Sankeng Old Street are straight and open. In the early years, there were pork chops, rice mills, two Chinese pharmacies, and coffin shops in Sankeng Old Street catering for all stages of life including birth, old age, illness, and death. In 1917, when Taoyuan Dazhen was built, the population exceeded 6000 [54].

The construction of Sankeng City Street, which has always been prosperous, started in Dazhen, Taoyuan in 1924 and was planned to take water from Shimen through Daping, Sankeng, and other places. Therefore, a light railway was built near Sankeng to facilitate the transportation of construction materials. During the construction period, many workers were introduced into Sankeng and brick kilns were even set up, thereby transforming the original agricultural market into a prosperous place for industry and commerce [57]. However, Taoyuan Dazhen caused the water level of the Dahan River to drop and affected shipping. In the period of the National Government, the construction of the Shimen Reservoir directly affected the water level of the Dahan River, and the development of shipping gradually disappeared. As a result, the Sankeng area saw three different prosperous periods, one being the beginning of reclamation, the other the construction 
of Taoyuan Dazhen, and the third the construction of the Shimen Reservoir. All three developments have seen reservoir immigrants with different needs. However, after the construction of the reservoir, because it was close to the NCSIST and the water source, Sankeng was also faced with the restrictive policies of Shimen Urban Planning and the construction of Taiwan-Sanyi Road. Like the Daping Community, vehicles cannot enter the community, which directly affects its development. The policy of road-building and restricting construction may have affected the construction and development of Sankeng, but like the Daping Community, it also remains a quite complete Hakka settlement.

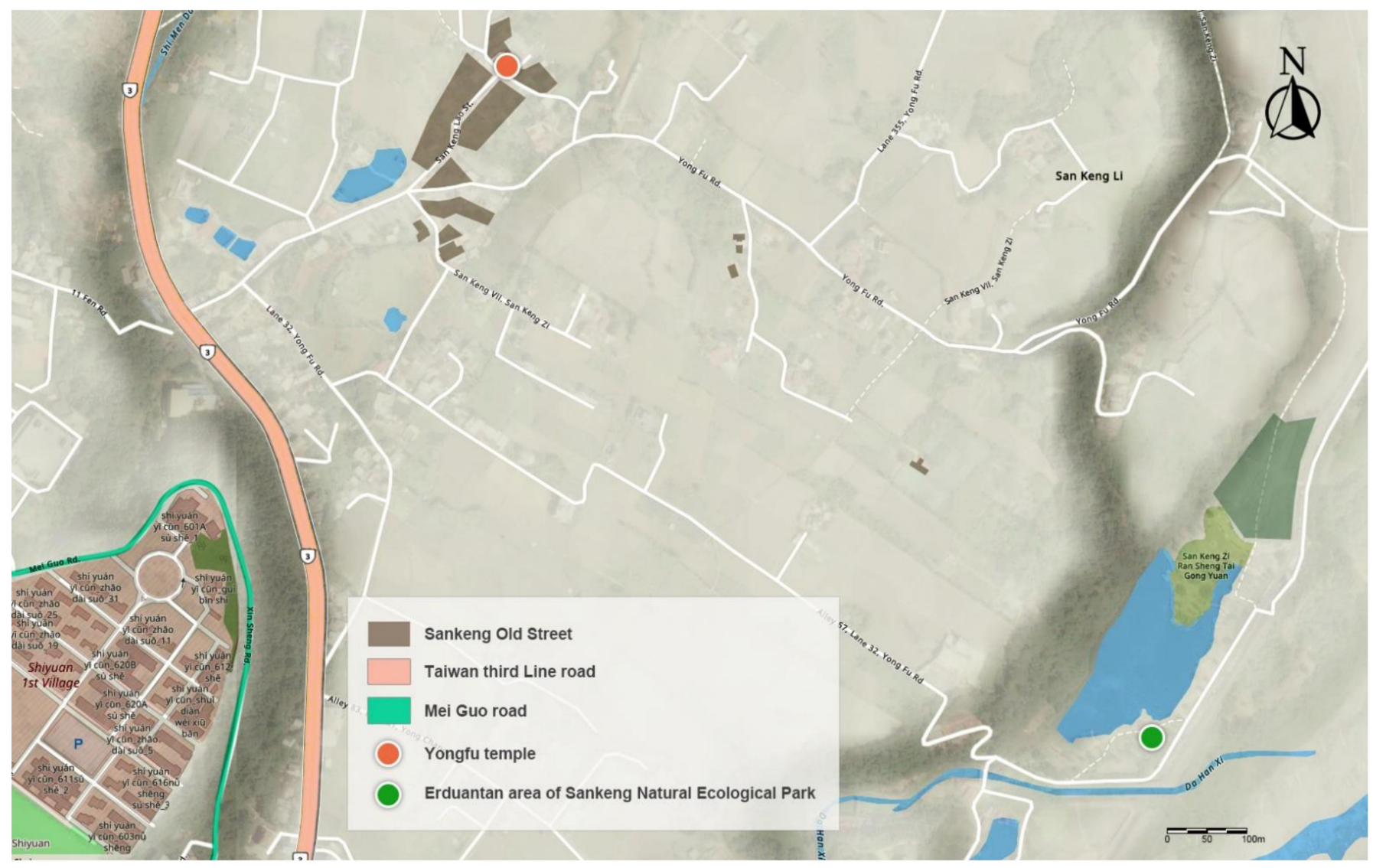

Figure 8. Sankeng Old Street and Sankeng Natural Ecological Park. Sources: Esri, DeLorme, HERE, TomTom, Intermap, increment P Corp., GEBCO, USGS, FAO, NPS, NRCAN, GeoBase, IGN, Kadaster NL, Ordnance Survey, Esri Japan, METI, Esri China (Hong Kong), swisstopo, MapmyIndia, and the GIS User Community.

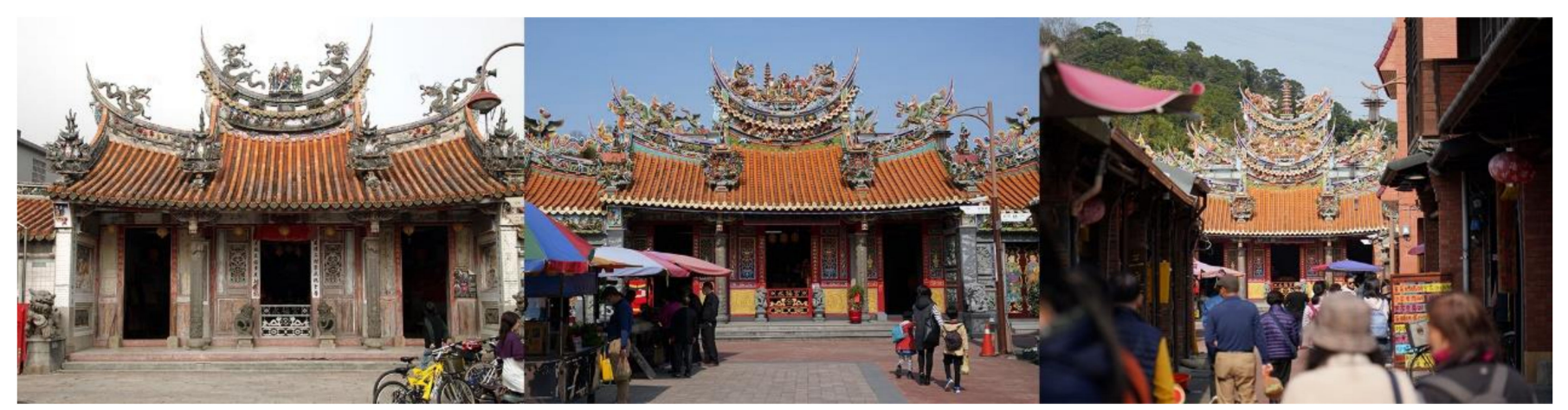

Figure 9. Before and after the construction of Yongfu temple in Sankeng Old Street (source: Wen-Zhe Hsieh, all rights reserved and used with permission).

Unlike the Daping Community, the Sankeng Community has gradually developed bicycle sightseeing activities due to the growth in cycling and nature-based travel in recent 
years. With the renovation of the old Sankeng Erduantan Ferry Berth and the opening of the "Sankeng Natural Ecological Park" and "Sankeng Tea Port Water", which have been completed one after the other, the Sankeng Community has begun to drive the sightseeing development of the community so that Sankeng has become an important location for Longtan sightseeing so that during holidays it attracts even more people than the Shimen Reservoir and has become Longtan's newest tourist attraction.

\subsection{Current Situation of Sightseeing and Amusement Areas}

Upon completion of the Shimen Reservoir in June 1963, in addition to changing the structure of the population and developing a live fish, drinking, and catering industry, the Shimen Reservoir, which spans the Longtan and Daxi regions, had also spawned a sightseeing park industry surrounding the reservoir. The Shimen Reservoir's sightseeing industry is mainly concentrated in the locations of Nanyuan and Beiyuan. The tourism and food industry around the reservoir covers the area shown in Figure 10, including the current Nanyuan Park (1), the North Park parking lot, the hiking entrance to Shimen Mountain, and the Shiyifen area, where Shimen's live fish industry is concentrated.
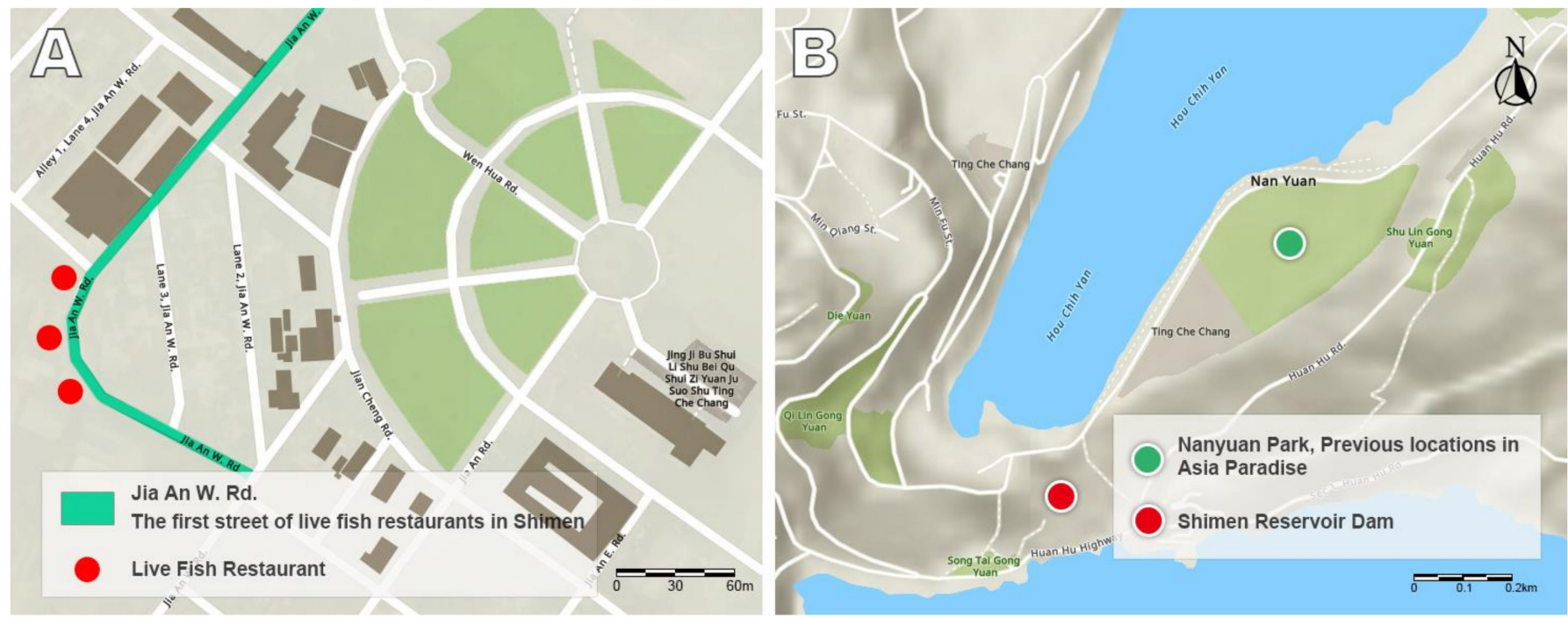

Figure 10. Survey Area Map. (A) The site of the Shimen Live Fish Restaurants is located around the Shimen Reservoir staff dormitory complex on Jia'an West Road. (B) Once the largest amusement park in Taoyuan, "Asia Paradise" was in the Reservoir Nanyuan Park. Sources: Esri, DeLorme, HERE, TomTom, Intermap, increment P Corp., GEBCO, USGS, FAO, NPS, NRCAN, GeoBase, IGN, Kadaster NL, Ordnance Survey, Esri Japan, METI, Esri China (Hong Kong), swisstopo, MapmyIndia, and the GIS User Community.

In The Educator Monthly, published in 1969, Mr. Wei-Kuan Liu noted, "It is not the first time for me to visit Shimen Reservoir. I went there as far back as the year Shimen Reserve [sic] was completed, but that time I went with friends and made a special trip..." [58]. The article's content tells us that traveling to the reservoir at that time may have been a fashionable thing to do. In 1971, the government stated that the "Shimen Reservoir Tourism policy is based on the principle of encouraging private investment" [58]. Promoted by Taoyuan Tourism Association, driving the local entertainment and tourism industry [59]. Therefore, large-scale amusement theme parks, sightseeing hotels, yachts on the lake, and other tourism industries were built around the reservoir. The sightseeing trend attracted tourists from all over Taiwan to visit the reservoir park in great numbers.

However, the good times did not last long. Asia Paradise closed in 1998 because of the change of ownership since its opening in 1978, but it was not demolished until 2005. During this period, Shimen Reservoir was struck by Typhoon Aere in 2004. The rainfall in the catchment area exceeded $970 \mathrm{~mm}$, and the hillside of the catchment area collapsed. As a result, muddy soil flowed into the reservoir, which caused its turbidity to rise sharply, 
i.e., to more than $10,000 \mathrm{NTU}$, and caused a severe shortage of water supply in the Taoyuan area [60]. Nearly one million residents in Taoyuan County fell into the nightmare of having no water available for half a month, setting a record for Taiwan's most extended and most widespread water cut [61].

The affected area where no water was available included Dasi in Nantaoyuan District, Longtan, Jhongli, Pingihen, and even Bade in North Taoyuan. According to Interviewee $\mathrm{D}$, "When the water supply was cut off at that time, it was very inconvenient to go to the nearby assembly place and other fire brigade waterwheels to pick up water. It was even more painful for residents living in old apartments on higher floors. Some veterans and old men were not easily moved, and it became very troublesome to pick up water".

Interviewee E, living in Bade, Taoyuan, recalled, "At that time, there were already two water towers in the family, but the water was not enough. In the old house before, there was a well in the middle of the two households. We had the motor installed, and the water from the well was used for flushing toilets and watering flowers. In this way, we barely survived".

After the impact, the Shimen Reservoir began to carry out the six-year Shimen Reservoir Catchment Regulation Plan in 2006 [62], to improve soil and water conservation and desilting operations around the catchment. As a result, the large amusement park around the reservoir closed and the development plan stopped. The closed Asian Paradise had no possibility of recovery and was finally demolished in 2005. The current site is planned as "Nanyuan Park", which has become another hiking area of the reservoir. Now, it has become the "Shimen Reservoir, Hot Air Balloon Carnival" venue, operating from June to July every year. Looking at the current site, we can no longer imagine the scenery of the former Asian Paradise.

Since the failure of Asian Paradise and with the fading of the Shimen Reservoir, the tourism industry in the neighborhood went in rapid decline. From the peak of nearly 3 million people a year, by the time it was reported in 1994, there were fewer than 1.3 million visitors. The fierce competition among amusement areas [63] accelerated the decline of the tourism industry around the reservoir.

\subsection{Live Fish Tourism Industry}

During the reservoir construction period, a temporary iron house was built at the present position of the Huancui Building at the head of the dam to meet the dietary needs of the large number of construction workers who moved to Shiyifen [43]. Upon the reservoir's completion, a modern reinforced concrete building was built on the site of the original small shop at the head of the dam selling groceries. Huancui Building Restaurant followed suit and became the Shimen Reservoir's earliest restaurant providing live fish dining and drink. Now, Huancui Building has developed into the Shimen Reservoir Tourist Information Center, the Management Center Office, and other administrative facilities.

The live fish industry around the Shimen Reservoir is widely distributed, extending from Jiayuan Road and Wenhua Road to the top of the dam, and has proved to be popular. At first, the Shimen Reservoir Management Center allowed people in the flooded area to operate lake tours on the water, engage in fishing and provide their catch to restaurants along the lake, and begin attracting hotel operators to enter the back pool weir one after another. Hotels, parks, and restaurants also attracted many tourists [64]. However, the original live fish restaurant was not a restaurant located around the lake, but a "Jinlan Fresh Fish Restaurant" located in the Shiyifen dormitory area and Jia'an road, along with restaurants such as "Nanyuan Live Fish" and "Shiyuan Live Fish". The main customers served by these restaurants were the employees of the Shiyifen dormitory group and their families [65]. The famous live fish-eating style began with "Shiyuan Live Fish" located in Jia'an West Road, which became a prosperous place for Shimen live fish and was called the Shimen Live Fish Street (Figure 11) by local people. 

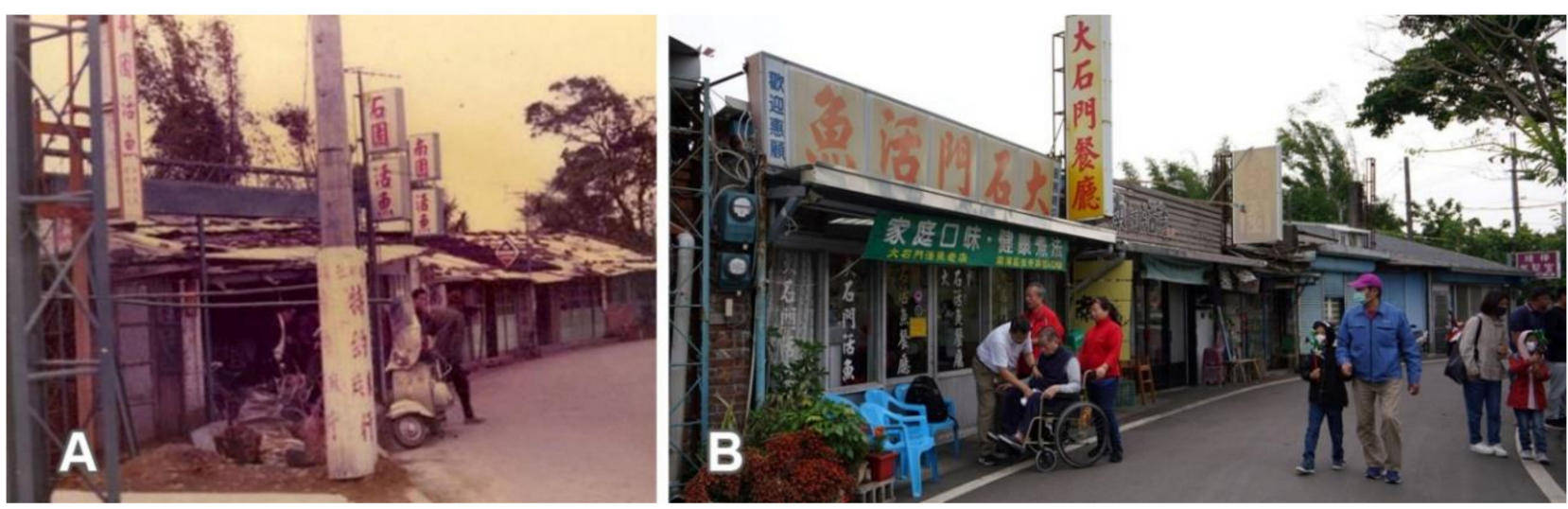

Figure 11. The area where the first live fish restaurants started. (A) The first 'street of live fish', photographed around the 1970s. (B) The first 'street of live fish' as it is now, photographed in 2021 (source: Shiyifen Cultural and Creative Park Resident Workstation and Wen-Zhe Hsieh, all rights reserved and used with permission).

Compared with the decline of the sightseeing park, the live fish industry has seen rapid development year by year. Almost all visitors come to the reservoir to eat live fish. The original 'live fish street' has gradually developed into Wenhua Road, Sankeng Community, and Daxi Sec with 5 Kangzhuang Road, forming the live fish sightseeing industry. According to the Shimen Reservoir Global Information Network data, there are currently 45 live fish restaurants registered on the Internet. It has been 16 years since the Taoyuan City Government held the first Shimen Live Fish Festival in 2004, which shows that the live fish tourism industry has not been strongly affected by the closure of the parks.

From 2020 to 2021, because of the severe water shortage in the Shimen Reservoir and the severe impact of the COVID-19 epidemic in Taoyuan in May 2021, the Shimen Reservoir was closed. Live fish operators were doubly affected. The restaurant business is only $10 \%$ of what it was before COVID-19. Live fish industry interviewee F said, "The water level has dropped, we can't catch fish, and with the impact of the COVID-19 epidemic, we haven't had any customers recently". Many operators have had no fish to sell and have closed their premises. Even if the epidemic has recently subsided and the reservoir reopens, the water situation will make it impossible for operators to resume operations [66].

\section{Discussion}

The initial development of the Longtan area started from Sankeng, as the water transport along the Dahan River could directly reach Danshui, and the trade in tea formed a distribution center for the local area [55]. It was also the starting point of the freight trade [56]. Compared to the geographical location of Sankeng, Daping was closer to Shimen Gorge, so the defensive structures in Daping were most likely built by the Han to defend against the aborigines [53] and to protect Sankeng as an essential trading port. There were three periods when Daping and Sankeng were developed; one was the period of the Qing Dynasty when the Han Chinese opened the area for trade. One was the period of Japanese rule when Taoyuan began to carry out water conservation projects. The last one is the present time when the Shimen Reservoir was built [29].

During the Japanese rule period, the construction of canals began, among which the Taoyuan canal, completed in 1928, is the most representative [29]. After the Taoyuan Canal's completion, Taoyuan farmers started growing rice and reducing the cultivation of tea [67]. However, the completion of the Taoyuan canal intercepted a large amount of water from the upper reaches of the Dahan River, which affected the water volume in the middle and lower reaches and led to a reduction in the navigation of the Dahan River, even changing the original agricultural pattern [68]. With the reservoir's completion, the Shimen area, which was initially a tea-growing area, has evolved into a tourist attraction with natural scenery and live fish restaurants [29]. 
From the initial construction of the reservoir, the temporary dormitory in Erping was built for the convenience of the construction industry, which also made the neighboring community of Daping busy and lively. Nevertheless, with the completion of the reservoir, the demolition of the Erping dormitory, and the widening of the Taiwan Third Road and other traffic factors, the community became deserted, and the buildings gradually fell into disrepair. Although in recent years the Daping Red Bridge has become a tourist hotspot due to the attention of the tourism industry, the route has prevented the development of the community. However, Sankeng, which is also an old community, has a dedicated road for bicycles that leads directly to Daxi and Yingge, including the planning of a nature park, which is a perfect complement to the bicycle tour that has been promoted in recent years, making Sankeng a popular area for tourism in Longtan and making it even more crowded during holidays, bringing real help to the local economy.

The newly built dormitory complex is different from the old neighborhoods of Daping and Sankeng, which are the property of government departments. Therefore, with the construction of the reservoir more than 50 years ago, the people and premises living in the Jia'an Road dormitory have been gradually aging. The government hopes to propose improvement strategies for the revitalization of the community. Although there is still no consensus with the administration, a more resounding agreement has been forged among the residents. This is a positive development for the community. In addition, the dormitory colony has changed the food culture in the Shimen area. The live fish diet that has emerged from Jia'an Road originates from the aquaculture of the Shimen Reservoir itself, which is the industry most directly related to the reservoir. Almost all the restaurants around the reservoir are related to living fish, and "live fish" has become a synonym for the diet of Shimen Reservoir [69]. For tourism destinations, food and beverage tourism can bring economic prosperity to the area, enhance local attractions and their appeal, and increase tourists' interest in the area [70].

Large reservoirs can also serve an important environmental function, as they can be used to ensure environmentally safe flow rates in waterways during droughts [71] and have benefits such as water supply, power generation, and tourism, but factors including design, location, and efficiency can still have a significant negative impact on ecosystems [72], as exemplified by the Oroville Dam in the United States, where spillway damage in February 2017 and Hurricane Harvey in September of the same year caused significant damages to the reservoir [73] and forced the evacuation of nearly 188,000 residents [74].

However, inappropriate tourism development can also lead to depletion or even degradation of tourism site resources [37]. Overdevelopment may lead to increasing siltation of reservoirs [39], and typhoon Aere in 2004 [38] caused huge earth and sand slides that wreaked havoc on the catchment area of the Shimen Reservoir. The prominent landslides were in the western half of the catchment area around Yufeng and Baishi [75], which caused the reservoir's water quality to deteriorate due to siltation and severely affected people's lives. It also directly affected the surrounding amusement parks and hotels, which were closed.

Although Taiwan faces strong typhoons or seasonal rainfall every year, the water shortage dilemma cannot be ruled out every year. From Figure 12, the rainfall data from 1965 to 2020 at the Shimen rainfall station (excluding the missing data in 2015 and 2017) shows that the annual rainfall in 2020 was the lowest for the past 55 years (only $1671 \mathrm{~mm}$ ).

Under the influence of global climate change, "disaster normalization" has become a trend that cannot be ignored. The continuous climate change affects the field of climatology and hydrology, directly affecting the reliability of water resources and the availability of water supply from reservoirs [76]. 


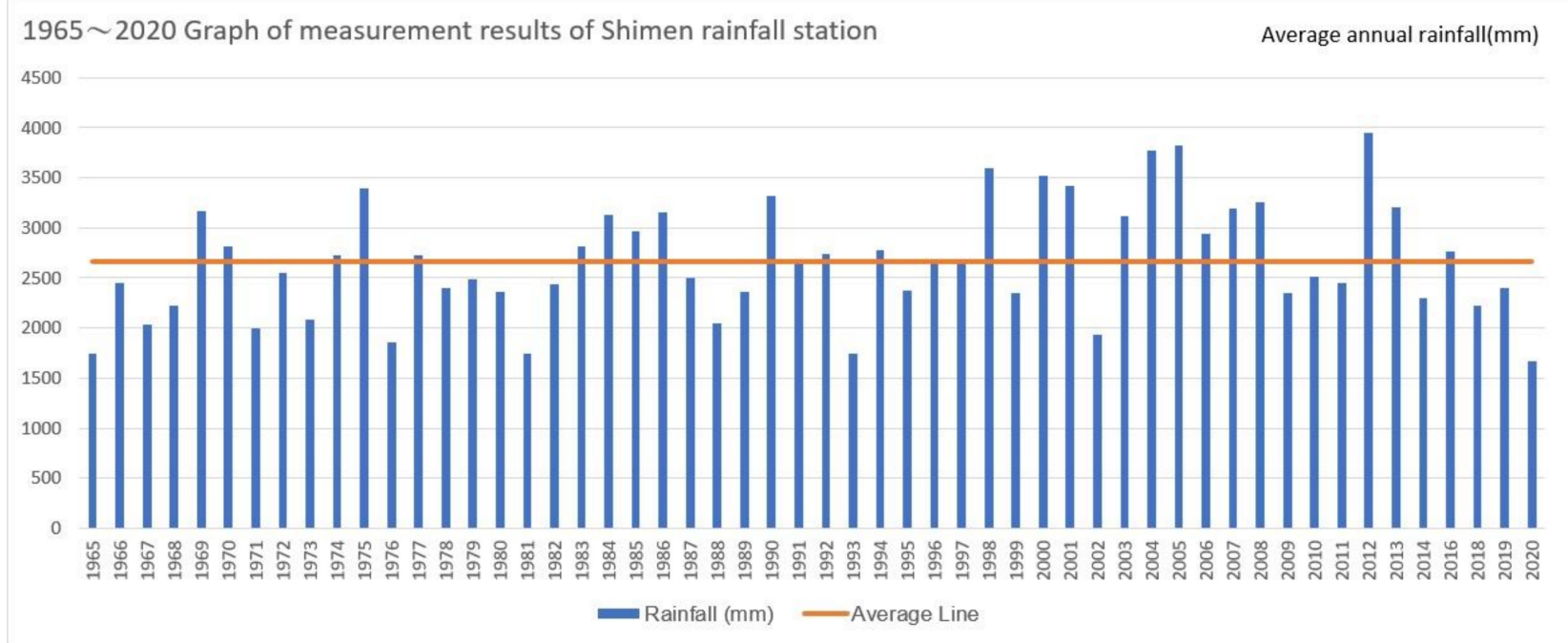

Figure 12. 1965 2020 Graph of measurements at the Shimen rainfall station (excluding the missing data in 2015 and 2017). Source: gweb.wra.gov.tw Water Resources Department, Ministry of Economic Affairs. Sources: Water Resources Agency, MOEA. (accessed on 22 October 2021).

With an average of 3.5 typhoons per year, climate anomalies have greatly affected Taiwan [77]. The year 2020 was the first time since 1964 that Taiwan was not hit by a typhoon [78], which caused a water shortage in the Shimen Reservoir. The water shortage not only increased the pressure on the water supply in the Taoyuan area, but also caused the tourism industry, such as yachts and restaurants, which were initially dependent on the reservoir, to decline gradually until today (June 2021). It has been 57 years since the development of the Shimen Reservoir, and due to the aging of the dam and reservoir, a comprehensive dam safety plan must be developed [79]. Therefore, the vulnerability study of the social-ecological system (SES) based on tourism around the reservoir is essential for future development [33] and to cope with the possibility of reservoirs facing complex hazards in the future.

Overall, the Shimen Reservoir remains the most critical water conservation facility in Taiwan. The canals connected to the reservoir's extension provide water for agriculture, industry, and people's livelihoods in the greater Taoyuan area. However, the transformation into a new cultural landscape has been an essential element in sustaining social development $[4,26]$. Tourism activities around the reservoir continue to influence the surrounding economic, cultural, social, and ecological environment [37]. The nature of the reservoir itself helped it to quickly become a popular tourist area, and the villages and communities linked to the reservoir have entirely changed the way of life around the reservoir.

\section{Conclusions}

The impact of reservoir construction on the environment has become an important global issue, as reservoirs directly affect the supply of water, electricity, community development, and the development of tourism and food industries based on their unique landscape characteristics. This paper presents the development and status of the impact of the reservoir on the local community through a case study of the community surrounding the Shimen Reservoir in Taiwan. The main findings are:

1. After the reservoir was built, the change in lifestyle, including the newly established dormitory clusters, has created a new type of community where community residents come together to reach a consensus and pursue better development. However, it has dramatically affected the original old streets and villages. Due to the constraints of urban planning, road planning, and other factors, the old streets could not develop 
and gradually declined. Only Sankeng has developed its unique tourism model, which continues to attract visitors.

2. With the reservoir's completion, the natural landscape has changed, and tourism development has changed the surrounding food culture. Still, only the tourism industry, which has a symbiotic relationship with the reservoir, can drive local economic growth and become an essential resource for the local economy.

3. The impact of climate change on the function of the reservoir, in the face of reduced rainfall and the COVID-19 epidemic, not only affects the water supply and power generation, but also has a significant impact on the tourism industry of the reservoir, which seriously affects the lives and incomes of residents.

The findings suggest that the uniqueness of the local environment and natural landscape is shaped by the residents, who also shape the local cultural landscape, lead the community's industrial development, increase the economic cycle, and achieve sustainable development. The development patterns of communities and reservoirs can be transferred to other communities that emerge from reservoir construction through model transfer. However, the rapid social and ecological changes, coinciding with the impact of water shortage and the epidemic in this study case, have led to a sharp decline in the economic benefits of reservoir tourism this year (2021). Therefore, studying the vulnerability of socioecological systems based on reservoir tourism is imperative in order to build a resilient society and achieve good health and well-being.

Author Contributions: Conceptualization, L.-Y.C.; W.-Z.H.; R.-J.C.; Formal Analysis, L.-Y.C.; W.-Z.H.; R.-J.C.; Funding Acquisition, L.-Y.C.; R.-J.C.; Investigation, W.-Z.H.; Methodology, L.-Y.C.; W.-Z.H.; R.-J.C.; Writing-Original Draft, W.-Z.H.; Writing_-Review and Editing, L.-Y.C.; R.-J.C. All authors have read and agreed to the published version of the manuscript.

Funding: University Foresight Education Project, Ministry of Education, Taiwan. Project Title: Water Matter - Smart Governance of Water Resources toward Resilience (B-052-110-3-0011).

Institutional Review Board Statement: Not applicable.

Informed Consent Statement: All participation was voluntary and Verbal Informed Consent was obtained from the interviewees.

Data Availability Statement: Not applicable.

Conflicts of Interest: The authors declare no conflict of interest.

\section{References}

1. Kang, P. Concept of Region in Geography and the Discourses on the Eastern Taiwan Studies. J. East. Taiwan Stud. 2000, 5, 17-33.

2. He, L.D. Landscape Diversity and Landscape Conservation. Sci. Dev. 2009, 7, 22-29.

3. Liu, T.C.; Lee, S.H.; Hou, J.S. The Revitalization of Degrading Cultural Landscape the Spatial Signification of Historical Railway of Tai-An Village. J. Geogr. Sci. 2011, 61, 147-166.

4. UNESCO. Operational Guidelines for the Implementation of the World Heritage Convention; UNESCO World Heritage Center: Paris, France, 2019; Volume 1, p. 83.

5. Wang, W.C. Spatial Analysis of Urban Landscape Change in Kaohsiung. Ocean. Cult. J. 2008, 4, 195-223.

6. Hu, E.W. Hong Kong Style 2 Destroy Hong Kong; Zuni Icosahedron: Hong Kong, China, 2006.

7. Wang, C.H. Dialectics in Multitude an Exploration Into/Beyond Henri Lefebvre's Conceptual Triad of Production of Space. J. Geogr. Sci. 2009, 55, 1-24.

8. Cheung, S.M. Space and Capitalist Society. Lunching Cult. Studies Lingnan 2008, 10, 9.

9. Lefebvre, H.; Nicholson-Smith, D., Translators; The Production of Space; Wiley Blackwell: Hoboken, NJ, USA, 1991; pp. 38-52.

10. Chen, H.T. The Establishment and Operation of Irrigation Business in the Period of Taiwan under Japanese Occupation: Exemplified by the Irrigation of Chia-nan System. Fu Jen Hist. J. 2001, 12, 117-152.

11. Lee, L.Y. From Canal to Reservoir: Construction and Land Use of Shimen Reservoir. Taoyuan J. Hist. 2016, 1, 79-86.

12. Tseng, L.W. Study on the History of Land Development of Shimen Reservoir-The Beginning of the Construction of the Dam. Ecol. Taiwan 2004, 3, 31-34.

13. Lin, B.Y. Wei da Taiwan de Mei Yuan (1949-1957): V.S. de Beausset's Order of Brilliant Star; Lin Bingyan: Taipei, Taiwan, 2004.

14. Sun, C.T.; Yen, A.C. An Investigation of Watershed Management and Land Ethics-A Case of Indigenous Communities on Upstream Shimen Reservoir Catchments Area. J. Geogr. Sci. 2004, 66, 21-51. 
15. Shimen Reservoir Construction Committee. Shimen Reservoir Construction History; Shimen Reservoir Construction Committee: Taoyuan, Taiwan, 1966.

16. Hung, Y.N.; Shiau, J.T. Impacts of Optimal and Fuzzified Rule Curves on Water Deficits for Nanhua Reservoir. J. Taiwan Agric. Eng. 2017, 63, 67-77.

17. Ouyang, J.H.; Yu, T.Y. Taiwan's Strategy for Efficient Use of Water Resources. CTCI Found. 2014, 5. Available online: https: / / www.ctci.org.tw/8838/publication/10798/15815/ (accessed on 30 August 2021).

18. Li, Y.J. Water Resources Management in Response to Climate Change. Econ. Outlook Bimon. 2013, 147, 8-12.

19. Water Resources Agency. Statistical Report on Water Storage Facility Operation in Taiwan; Water Resources Agency: Taichung, Taiwan, 2008; Volume 98, p. 12.

20. Lee, G.C. Cultural Landscape and Community Development. Sci. Dev. 2009, 439, 38.

21. Wittfogel, K.A. Oriental Despotism: A Comparative Study of Total Power; Yale University Press: New Haven, CN, USA, 1957.

22. Pasternak, B. The Sociology of Irrigation: Two Taiwanese villages. In Economic Organization in Chinese Society; Willnott, W.E., Ed.; Stanford University Press: Palo Alto, CA, USA, 1972; pp. 193-213.

23. Drakou, E.G.; Kallimanis, A.S.; Sgardelis, S.P.; Pantis, J.D. Landscape structure and habitat composition in reservoirs, lakes, and rivers. Lake Reserv. Manag. 2008, 24, 244-260. [CrossRef]

24. Rosenberg, D.M.; McCully, P.; Pringle, C.M. Global-Scale Environmental Effects of Hydrological Alterations: Introduction. BioScience 2000, 50, 746-751. [CrossRef]

25. Popp, A.; Hoagland, D.K. Changes in benthic community composition in response to reservoir aging. Hydrobiologia 1995, 306, 159-171. [CrossRef]

26. Havel, J.E.; Lee, C.E.; Vander Zanden, J.M. Do Reservoirs Facilitate Invasions into Landscapes? BioScience 2005, 55, 518-525. [CrossRef]

27. Daus, M.; Koberger, K.; Gnutzmann, N.; Hertrich, T.; Glaser, R. Transferring Water While Transforming Landscape: New Societal Implications, Perceptions and Challenges of Management in the Reservoir System Franconian Lake District. Water 2019, 11, 2469. [CrossRef]

28. Bär, S. Ganzheitliches Tourismus-Marketing. In Die Gestaltung Regionaler Kooperationsbeziehungen; Deutscher Universitäts-Verlag: Wiesbaden, Germany, 2006; ISBN 978-3-8350-0275-3.

29. Chen, C.P. A Study of the Transformation of Cultural Landscape with the Viewpoint of Irrigation Constructions by the Example of Taoyuan County throughout the Century (1900-2000). J. Archit. 2013, 85, 77-98.

30. Wang, S.C. Rural Social Relations from the Development of Taiwan's Farmland Water Resources in the Qing Dynasty. Taiwan Hist. 1985, 36, 107-150.

31. Chen, F.H. The Development of Irrigation and the Change of Spatial Organization in Tao-Yuan Tableland. Dep. Geogr. NTNU 1979, 5, 49-77. Available online: http:/ / rportal.lib.ntnu.edu.tw/handle/20.500.12235/23667 (accessed on 21 October 2020).

32. Zhao, D.; Xiao, M.; Huang, C.; Liang, Y.; An, Z. Landscape Dynamics Improved Recreation Service of the Three Gorges Reservoir Area, China. Int. J. Environ. Res. Public Health 2021, 18, 8356. [CrossRef] [PubMed]

33. Tu, J.; Luo, S.; Yang, Y.; Qin, P.; Qi, P.; Li, Q. Spatiotemporal Evolution and the Influencing Factors of Tourism-Based SocialEcological System Vulnerability in the Three Gorges Reservoir Area, China. Sustainability 2021, 13, 4008. [CrossRef]

34. Bossel, H. Indictors for Sustainable Development. Theory, Method, Applications; International Institute for Sustainable Development: Winnipeg, MB, Canada, 1999.

35. Wang, Q.; Yin, M.H.; Yang, X.Z.; Yao, Z.Z. Spatio-temporal evolution and impact mechanism of socio-ecological system vulnerability in poor mountainous tourist destinations: Taking dabie mountain area as example. Acta Geogr. Sin. 2019, 74, 1663-1679. Available online: http:/ / rwdl.xisu.edu.cn/CN/abstract/abstract12325.shtml (accessed on 20 September 2021).

36. Huang, C.; Huang, X.; Peng, C.; Zhou, Z.; Teng, M.; Wang, P. Land use/cover change in the Three Gorges Reservoir area, China: Reconciling the land use conflicts between development and protection. CATENA 2019, 175, 388-399. [CrossRef]

37. Zhao, H. A Review on the Adaptability of Tourism and Social-Ecosystem. J. Serv. Sci. Manag. 2018, 11, 565-577. [CrossRef]

38. Chen, J.K.; Lin, B.H.; Ji, S.Y. Assessment of man-made and natural rehabilitation of the collapsed land in the catchment area of Shimen Reservoir after Typhoon Avery. Sinotech Eng. 2014, 124, 51-59.

39. Sun, C.T. An Investigation of Human-Land Relationship and Social-Ecological Systems Resilience-A Case on Upstream Shimen Reservoir Catchments Area. Land Issues Res. Q. 2021, 32, 1-64. Available online: https://hdl.handle.net/11296/cc2jvv (accessed on 15 September 2021).

40. Casado-Arzuaga, I.; Onaindia, M.; Madariaga, I.; Verburg, P.H. Mapping recreation and aesthetic value of ecosystems in the Bilbao Metropolitan Greenbelt (northern Spain) to support landscape planning. Landsc. Ecol. 2014, 29, 1393-1405. [CrossRef]

41. Paleo-Torres, A.; Gurley, K.; Pinelli, J.-P.; Baradaranshoraka, M.; Zhao, M.; Suppasri, A.; Peng, X. Vulnerability of Florida residential structures to hurricane induced coastal flood. Eng. Struct. 2020, 220, 111004. [CrossRef]

42. Fischer, J.; Gardner, T.A.; Bennett, E.M.; Balvanera, P.; Biggs, R.; Carpenter, S.; Daw, T.; Folke, C.; Hill, R.; Hughes, T.P.; et al. Advancing Sustainability through Mainstreaming a Social-Ecological Systems Perspective. Curr. Opin. Environ. Sustain. 2015, 14, 144-149. [CrossRef]

43. Christian, F. Henri Lefebvre's Theory of the Production of Space and the Critical Theory of Communication. Commun. Theory 2019, 29, 129-150. 
44. Georgousis, E.; Savelidi, M.; Savelides, S.; Holokolos, M.-V.; Drinia, H. Teaching Geoheritage Values: Implementation and Thematic Analysis Evaluation of a Synchronous Online Educational Approach. Heritage 2021, 4, 195. [CrossRef]

45. Braun, V.; Clarke, V. Using thematic analysis in psychology. Qual. Res. Psychol. 2006, 3, 77-101. [CrossRef]

46. Lin, P.H. Comparison of data analysis of different qualitative research methods. In The Heteroglossia of Qualitative Research Methods; Zhou, P., Yang, H., Eds.; Institute of Sociology Nanhua University: Chiayi, Taiwan, 2007; pp. 127-149.

47. Chen, C.P. The People's Story of Mobility: A Study of the Migration due to the Construction of Reservoir in Taoyuan County. J. Geogr. Sci. 2012, 64, 67-96.

48. Huang, C.M.; Yu, H.T.; Su, C.; Huang, Y.Y. Basic Research of the Effects of US Aid on Shimen Water Reservoir Engineering Techniques. In National Science Council Result Report; Project Number: NSC 100-2221-E-033-076; National Science Council: Taoyuan, Taiwan, 2012.

49. Lin, W.C. Water, Power and Mobilities: A Discussion of Fen Space Transformation of Shi-I-Fen Community due to the Construction of the Shi-Men Reservoir; Graduate School of Interior Design, Chung Yuan University: Taoyuan, Taiwan, 2008; pp. 1-229.

50. Chiang, P.M. Research on community brand reengineering a study of Longtan Shiyifen. In Proceedings of the LSHI 2018: International Conference of Cultural Heritage and Design Innovation, Taoyuan, Taiwan, 25-27 October 2018; pp. $191-201$.

51. CHEN, S.R. The "Shiyifen Tourism and Cultural Park" is Now Open! Experience the Charm of the Family Village Where "Our Times". Available online: https://udn.com/news/story/7206/4040881 (accessed on 15 March 2021).

52. Shiyifen Cultural and Creative Platforms Construction and Counseling Project-“Revitalizing the old Shiyifen dormitory complex and shaping a new base for Taoyuan culture and creativity". Available online: https://tour.tycg.gov.tw/zh-tw/majorproject/ hightlight/10 (accessed on 10 September 2021).

53. Huang, C.L. Taoyuan County Historic Building "DaPing Bridge" Research and Restoration and Reuse Project; Cultural Affairs Bureau of Taoyuan County Government: Taoyuan, Taiwan, 2012.

54. Huang, C.L. Research and Restoration Project of "Longtan Township Sankeng Village Weng House" (Chuan Sheng Xin Ji Shop), a Historical Building in Taoyuan County; Cultural Affairs Bureau of Taoyuan County Government: Taoyuan, Taiwan, 2012.

55. Hakka, T.V. Exploring the Starting Point of Taiwan Taiwan Third line and Reproducing the Elegance of Erduantan Ferry Berth. Hakka TV. 2017. Available online: https:/ / www.youtube.com/watch?v=Ct2tI9aD2gM (accessed on 10 July 2021).

56. CommonWealth Magazine Humanities Publishing Featured Author Group. Romantic Taiwan's Third-Line Spiritual Footprints; CommonWealth Magazine \& Hakka Committee: Taipei, Taiwan, 2019.

57. Liu, W.G. Travelogue of Shimen Reservoir. Educ. Mon. 1969, 22, 33.

58. Minsheng Daily. Taoyuan County accelerated the development of local tourism business and held a joint meeting of committee members yesterday and approved a number of important proposals. In Taoyuan County Accelerated the Development of Local Tourism Business and Held a Joint Meeting of Committee Members Yesterday and Approved a Number of Important Proposals; Minsheng Daily: Taipei, Taiwan, 1971; p. 9. (In Chinese)

59. Wu, H.S. The six phases of Taiwan's four-year economic construction plan and the development of the tourism industry. Econ. Dly. News 1973, 6, 14. (In Chinese)

60. Lai, B.H.; Wu, C.S. Shimen Reservoir and its Catchment Management Project. RDEC Bimon. 2008, 32, 59-68.

61. Zhang, D.P. Rescue The Next Drop of Water, Our Island. 2011. Available online: https://ourisland.pts.org.tw/content/234 (accessed on 23 December 2020).

62. Ho, H.C.; Lin, B.S.; Chi, S.Y.; Chung, C.R.; Chiu, S.Y. Spatio-temporal Analysis for Landslide Change and Remediation Efficiency in Shih-Men Reservoir Watershed. J. Soil Water Conserv. Technol. 2012, 7, 174-188.

63. Long, Y.Y. Shimen tourism is frustrated, industry players criticize the authorities for not supporting. Econ. Dly. News 1994, 14 . (In Chinese)

64. Zhang, Z.H. Shimen Reservoir is famous for eating live fish. Econ. Dly. News 2001, 43, 29. (In Chinese)

65. Chang, H.C. Key Success Factors of Shimen Fresh Fish Restaurant; Chung Yuan Christian University: Taoyuan, Taiwan, 2018; pp. 1-99.

66. Chu, K.F.; Yang, Z.H.; Cheng, K.L.; Fan, W.T. Water and epidemic situation burned at both ends, Shimen Reservoir closed. United Daily News. Available online: https://udn.com/news/story/7324/5465078 (accessed on 20 April 2021). (In Chinese).

67. Chen, H.T. From Ponds to Irrigations: The Evolution of the Water Resources in Taoyuan Plateau. Dong Hwa J. Humanist. Stud. 2003, 5, 183-207.

68. Li, C.Y. The historical transition of the dispute of water conservancy in the irrigated area of Hòu Cun Zùn (1763-1945). Baisha J. GeoHistory 2012, 14, 65-169.

69. Pei, T.C.; Cheng, F.L.; Pei, C.Y. Importance-Performance Analysis: Application of the Satisfaction of Visitors Dining at Shimen Fresh Fish Restaurants. J. Manag. Pract. Princ. 2008, 2, 89-104.

70. Szivas, E. The Development of Wine Tourism in Hungary. Int. J. Wine Mark. 1999, 11, 7-17. [CrossRef]

71. Balvín, P.; Vizina, A.; Nesládková, M.; Blöcher, J.; Makovcová, M.; Moravec, V.; Hanel, M. Minimum Residual Flows for Catchments in the Czech Republic. Water 2021, 13, 689. [CrossRef]

72. Tahseen, S.; Karney, B.W. Reviewing and critiquing published approaches to the sustainability assessment of hydropower. Renew. Sustain. Energy Rev. 2017, 67, 225-234. [CrossRef]

73. Vano, J.A.; Miller, K.; Dettinger, M.D.; Cifelli, R.; Curtis, D.; Dufour, A.; Olsen, J.R.; Wilson, A.M. Hydroclimatic extremes as challenges for the water management community: Lessons from oroville dam and hurricane harvey. Bull. Am. Meteorol. Soc. 2019, 100, S9-S14. [CrossRef] 
74. Schmidt, S.; Hawkins, D. 'NOT a Drill': 188,000 Evacuated, Emergency Declared, as Calif's Massive Oroville Dam Threatens Floods. Washington Post. 13 February 2017. Available online: https://www.washingtonpost.com/news/morning-mix/wp/2017 /02/13/not-a-drill-thousands-evacuated-in-calif-as-oroville-dam-threatens-to-flood/ (accessed on 26 October 2021).

75. Lin, C.Y.; Lin, C.R.; Jeng, J.H.; Liu, C.W. Reasons for Sediment Disaster Caused by Typhoon Aere on Shimen Reservoir Watershed. J. Chin. Soil Water Conserv. 2006, 37-4, 327-336.

76. Sýs, V.; Fošumpaur, P.; Kašpar, T. The Impact of Climate Change on the Reliability of Water Resources. Climate 2021, 9, 153. [CrossRef]

77. Wang, J.J.; Yang, Y.Y.; Ke, C.J.; Hsu, T.Y. A Study on the Flood Risk Maps to Cultural Assets-Taking New Taipei City as an Example. J. Archit. 2014, 88, 175-191.

78. News Center. Because It Does Not even Come from the Typhoon! It Is the First Time in 56 Years That No Typhoon Has Hit Taiwan. 2020. Available online: https:/ / tw.appledaily.com/life/20201013/B5V4TVY7OND43HGFLZUTNW55XQ/ (accessed on 20 April 2021). (In Chinese)

79. Song, J.; Sciubba, M.; Kam, J. Risk and Impact Assessment of Dams in the Contiguous United States Using the 2018 National Inventory of Dams Database. Water 2021, 13, 1066. [CrossRef] 